\title{
COLleCtions MANAGEMENT ELLER SAMLINGSFORVALTNING
}

\section{Maiken Hansen}

Det administrative redskab collections management omfatter en rakke metoder og procedurer, der sikrer en sammenhangende forvaltning af samlingerne og en ultimativ udnyttelse af museets samlede resurser.

Mit indlag tager udgangspunkt $i$ det angelsaksiske begreb collections management, og indlagget er bade sprogligt og holdningsmassigt praget af denne tilgang til museologien. Sprogligt betyder det, at engelske udtryk forsøgsvist er oversat til dansk, men fordanskningerne skal opfattes som forslag, der til enhver tid er til diskussion. Holdningsmassigt betyder det, at der refereres til angelsaksiske - iser engelske - tilstande og holdninger ikke danske.

Indlægget skal ses som et forsøg på at puste liv $i$ en til en vis grad ikke-eksisterende debat: nemlig hvorvidt danske museer er opmærksomme over for problematikken omkring indsamlings- og bevaringspolitik. Mit indlæg er blevet til på baggrund af de publikationer, der på Museums Studies University College London i august 1998 anses for mest betydningsfulde inden for området.

\section{DEFINITION}

Samlingsforvaltning vil sige at forstå genstanden, dens autenticitet og dens betydning inden for de enkelte samlinger, at målrette indsamling og kassation, at sikre dokumentation og registrering, at sikre den korrekte behandling og undersøgelse af genstandene, at medvirke til ind- og udlån, at vurdere restaurerings- eller konserveringsbehov, at beskytte genstandene mod nedbrydning, katastrofer eller andre risici ved hjælp af sikkerheds- og kontrolforanstaltninger, samt at sikre offentligheden adgang til samlingerne. Det grundlæggende princip bag samlingsforvaltning er, at uden klare retningslinjer vil der til stadighed være risiko for, at individuelle beslutninger tages uden en samlet vurdering af helheden. Dette kan i bedste fald medføre resursespild, i værste fald ødelæggelse af genstande eller hele samlinger (Edson \& Dean 1994: 12; Stansfield 1994: 2-3). 
Retningslinjer der skal sikre kontinuitet og sammenhæng nedfældes $\mathrm{i}$ en såkaldt "collections management policy", det vil sige et dokument, der, ud over at fastlægge museets formål, indeholder retningslinjer og procedurer for samlingsforvaltningen (Edson \& Dean 1994: 67ff). Som med collections management, savnes et godt dækkende, dansk udtryk, så indtil videre bruges forvaltningsplan.

\section{KRAV VED ANERKENDELSE}

I såvel USA som i England betragtes behovet for at etablere disse retningslinjer og procedurer som et væsentligt skridt hen imod en yderligere professionalisering af museumsarbejdet. Konceptet for en forvaltningsplan blev udviklet i USA med det formål at forsikre offentligheden om, at man arbejdede $\mathrm{i}$ henhold til juridisk og etisk korrekte forholdsregler. Dette ledte til, at organisationer som ICOM, American Association of Museums og senere den engelske Museums Association i løbet af 1980 'erne udarbejdede retningslinjer (Codes of Conduct og Codes of Practice), der fastlagde ansvarsområder og procedurer (Stansfield 1994: 2). Nu om stunder kræver såvel den amerikanske Accreditation Commission som den engelske Museum \& Galleries Commission, at et museum der søger om at blive anerkendt (svarende til dansk statsanerkendelse) skal fremlægge en forvaltningsplan, der i det mindste indeholder en indsamlings- og kassationspolitik (Museums \& Galleries Commission 1995: 36).
Der er tre grundlæggende fordele ved en forvaltningsplan:

- den fungerer som et redskab til hjælp ved beslutningsprocesser. Med basis i en velgennemtænkt og velbearbejdet praksis for forvaltningen af samlingerne har man sikkerhed for, at hverken personale eller bestyrelse/offentlige myndighed eller andre personer tilknyttet museet træffer beslutninger inden for individuelle områder, uden at øvrige aspekter i forbindelse med samlingernes forvaltning har været overvejet.

- det daglige arbejde sikres en højere grad af kontinuitet og stabilitet, ligesom effektiviteten vil forbedres, fordi alle involverede ved, hvordan opgaver løses og hvilke langsigtede planer, der ligger inden for de enkelte områder.

- museerne kan demonstrere deres holdning til og forståelse for deres ansvar og tydeliggøre, at samlingerne administreres på grundlag af de legale og etiske krav, som offentligheden sætter.

En gennemarbejdet forvaltningsplan forklarer således, hvad museets formål er, hvorledes det udfører sine opgaver i henhold hertil og ud fra hvilke standarder opgaverne løses. Planen tages ideelt set op til revision efter 3 til 5 år (Edson \& Dean 1994: 36; Stansfield 1994: 8; Malero 1995: 11).

\section{UDARBEJDELSE}

Udarbejdelsen af en forvaltningsplan kan være et tidsrøvende og ganske langvarigt arbejde. Det kræver meget af personalet og bestyrelse/offentlige myndighed i form af fri og åbenhjertig kommunikation. Det 
er vigtigt, at områder eller arbejdsopgaver, som giver anledning til usikkerhed eller uenighed, bliver debatteret og at konklusionen som følge heraf indeholder justeringer, der afspejler eventuelle problemer. Men målet med planen er at definere ansvarsområder og udarbejde retningslinjer for de personer, der er beslutningstagere ved hjælp af en instruktiv og grundig beskrivelse. Målet er ikke at forsøge at løse alle tænkelige problemer eller gennemgå de enkelte arbejdsprocesser minutiøst. Dels bør en forvaltningsplan ikke være så stramt opbygget, at den ikke giver mulighed for ad hoc beslutninger, dels ændres arbejdsprocesser ofte løbende i forhold til antallet og arten af arbejskraft (Malero 1995: 12-13).

\section{INDHOLD}

De fleste engelske og amerikanske forvaltningsplaner afspejler ICOM's definition af, hvad et museum er og inddrager sædvanligvis punkterne: museets formål, indsamling, kassation, ind- og udlån, dokumentation, konservering, magasiner, pakning og transport, sikring af samlingerne, forsikring, offentlig adgang og udstillinger. Der er imidlertid museer, som «nøjes» med at sætte fokus på de områder, der er direkte knyttet til indsamlingspolitikken og undersøgelser af "the cost of collecting".

Faktisk understreger Anne Fahy i sin introduktion til "Collections Management", at de to forhold går hånd $\mathrm{i}$ hånd og skal betragtes under et: samtidig med at museerne udarbejder forvaltningsplaner for indsamling, opstår behovet for at undersøge de egentlige omkostninger. Når de er kendt, skal man sikre, at indsam- lingspolitikken udarbejdes således, at den er relevant $\mathrm{i}$ forhold til museets resurser (Fahy 1995: 7).

I England var det især en rapport fra 1989, der gav startskuddet til overvejelser vedr. disse forhold. I rapporten analyserede forfatterne de faktuelle omkostninger til erhvervelse, pasning, beskyttelse og dokumentation. Rapporten konkluderede, at uanset om genstande blev foræret til museet, ville der være udgifter forbundet med erhvervelsen, $\mathrm{fx}$ udgifter til pakning og transport af genstanden (især ved store eller skrøbelige genstande), foreløbig undersøgelse med henblik på videre behandling (rensning/restaurering/konservering), vurdering af dokumentation og endelig registrering. Hertil skal så lægges de fremtidige udgifter i form af behandling, magasinering, sikkerhed etc. (Lord, Lord \& Nicks 1989).

\section{FORVALTNINGSPLANENS $O M R A D E R$}

Forvaltningsplanens punkter rejser hver især et stort antal spørgsmål og en del af disse er gennemgået nedenfor. Gennemgangen er baseret på angelsaksiske holdninger og arbejdsforhold, som kan forekomme meget forskellig fra danske forhold.

\section{Definition af museets formål}

Det betragtes som essentielt, at museets formål og dermed arbejdsområder defineres. Områder som indsamling, kassation, typen af samlinger, brugen og målene for disse er $\mathrm{fx}$ alle områder, der er afhængige af, hvad museets ansvarsområde er (Edson \& Dean 1994: 69). Herudover omfatter punktet museets vedtægter og andre kontrakter eller legale forhold som museets, 
44 bestyrelsens eller myndighedernes roller. Desuden indgår forordninger eller nationale og internationale love, som museets arbejde er omfattet af, fx Konventionen vedr. handel med truede dyrearter (Stansfield 1994: 9). Også de forskellige typer af samlinger, $\mathrm{fx}$ særlige samlinger beregnet til skoler eller erhvervet til forskning skal beskrives. Endelig fastlægges særlige forhold i forbindelse med genstandes/samlingers opbevaring eller udstilling (Edson \& Dean 1994: 69).

\section{Indsamling}

Mange museer har akkumuleret deres samlinger om ikke direkte ved tilfældigheder, så dog alligevel mere som et resultat af omgivelsernes interesse og gavmildhed, end som et resultat af målrettet indsamling. Ved en fremtidig sikring af samlingernes relevans $i$ forhold til museets ansvarsområde bør man derfor overveje følgende punkter:

- forhold nævnt under punkt 1);

- omstændigheder under hvilke man vil acceptere erhvervelser, fx i forhold til krav fra donator eller manglende proveniens;

- hvorvidt genstanden/samlingen opfylder et savn i forhold til eksisterende samlinger og deres fremtidige behov og brug;

- faciliteter i form af personale og magasiner;

- resurser til undersøgelser og konservering;

- korrekte sikkerheds- og kontrolforanstaltninger;

- kollegiale overvejelser: er det genstande/samlinger andre museer bør tilbydes;

- hvordan tages beslutninger vedr. området og hvem har den endelige beslutningskompetence (Edson \& Dean 1994: 69ff; Stansfield 1994: 8ff).

\section{Kassation}

Kassationsmetoden er i mange tilfælde afhængig af årsagen til, at et museum ønsker eller muligvis er tvunget til at skaffe sig af med/afgive genstande. Området giver til stadighed anledning til diskussioner i såvel England som USA, og forhold under hvilke man vil afgive genstande skal grundigt overvejes. Listen skal indeholde forholdsregler i forbindelse med nedlæggelse af museet, men kan derudover medtage:

- restitution, dvs. tilbagelevering af genstande til nationer eller institutioner, der mener, de har et juridisk krav;

- repatriation, dvs. overgivelse af genstande til nationer eller etniske samfund, der mener at have et moralsk krav (Stansfield 1994: 10f);

- biologisk inficerede eller fysisk skrøbelige genstande, der er til fare for andre genstande/samlinger/personale/besøgende og som ikke kan behandles/konserveres betryggende (Sansom 1995a);

- genstande, der er så ødelagte, at de er nytteløse i udstillings- og forskningssammenhæng og som museet ikke har resurser til at behandle/konservere (Keene 1996: $71 \mathrm{ff})$;

- evt. dubletter, forfalskninger, kopier (Sansom 1995a);

- hvordan beslutninger vedr. området tages og hvem der har den endelige beslutningskompetence.

Nogle museumsfolk mener, at adgangen/adkomsten til at skille sig af med en genstand skal være meget restriktiv, idet man ellers sætter sin troværdighed over styr. Andre mener, at et museum generelt ikke bør have problemer med at skille sig af med genstande, som er erhvervet i tidligere tider og som nu ikke er omfattet af 
indsamlingspolitikken, såsom:

- genstande, som ikke længere er brugelige eller relevante $\mathrm{i}$ forhold til punkterne 1. og 2;

- genstande, som museet i længden vil have svært ved at opbevare/restaurere/konservere korrekt;

- genstande, som man ikke mener vil kunne udnyttes inden for en rimelig tidshorisont;

- genstande eller samlinger som bør opgives for at museet kan styrke andre områder (Edson \& Dean 1994: 70; Stansfield 1994: 8).

Uanset holdningen til hvor nem eller svær adgangen til kassation skal være, er der dog fra museernes side en klar holdning til nødvendigheden af at formulere en politik inden for området. Det er nødvendigt, at kassation ikke foregår efter vilkårlige principper, alt efter hvem der leder museet, hvem der sidder i bestyrelsen/offentlige myndighed, hvad der er oppe i tiden etc. (Babbridge 1995; Robertson 1995).

\section{Dokumentation}

Værdien af en genstand eller en samling er i høj grad afhængig af, hvor komplet og præcis dokumentationen er. I de angelsaksiske lande såvel som i Danmark bruges et antal forskellige registreringssystemer, som jeg ikke skal komme ind på her. De fleste større museer i UK og USA har en registrator, der udelukkende beskæftiger sig med indkomne genstande, samt ind- og udlån, forsikring og flytning. Samtidig er de fleste større museer i dag gået over til edb, og forvaltningsplanerne vil derfor naturligt afspejle begge disse forhold både i forbindelse med arbejdsområder og opgaver og $\mathrm{i}$ forbindelse med resurse-og ansvarsfordeling. Herudover vil punktet 45 muligvis omfatte museets ønsker og muligheder for forskning og de faciliteter, det kræver (Stansfield 1994: 23ff).

\section{Offentlig adgang}

Tilgængeligheden til museets genstande og samlinger forbedres i disse år takket være edb'ens muligheder. Som nævnt ovenfor er de forvaltningsplaner der udarbejdes nu og i de kommende år, optaget af museets holdning til og arbejde med edb'en. Hvis man ikke allerede bruger edb, skal man tage stilling til museets behov og krav, dernæst til hvilke(t) system(er) og maskinel der skal bruges. Desuden skal man vurdere hvad og hvor meget, man ønsker offentliggjort via edb'en, fx på Internettet og de nye ansvarsområder skal fordeles, lige som beslutningstagere skal udpeges.

Graden af offentlig tilgængelighed skal fastlægges, fx i forhold til hvor og hvem man vil acceptere $\mathrm{i}$ forskellige områder af museet og hvorledes man forholder sig til fx zoologiske eller geologiske prøvetagninger (Stansfield 1994: 5-6). Man bør også liste retningslinjer for hvordan, man forholder sig til andres brug af museets genstande/arkivmateriale etc. fx i forbindelse med forskning og efterfølgende offentliggørelse. Endelig bør man overveje graden af service over for borgerne ved ønsker om hjælp til identifikation, datering og vurdering af genstande (Stansfield 1994: 40).

\section{Ind-og udlàn}

Ind- og udlån skal ske under sikre forhold og omfatte retningslinjer for hvem eller hvilke institutioner, man vil låne ud til eller fra, samt hvem på museet som er ansvarlig for området. Hertil kommer ret- 
46 ningslinjer for hvor lang tid lånet kan løbe, hvem der er ansvarlig for omkostninger $\mathrm{i}$ forbindelse med lånet (pakning, transport, forsikringer etc.), hvilke krav man stiller til sikkerheden og de klimatiske forhold, hvilke restriktioner man sætter ved udstillinger, financielle forhold hvis $\mathrm{fx}$ låneinstitutionen kan sikre sig store indtægter i forbindelse med lånet, en beskrivelse af genstandens tilstand ved udlånet, klare aftaler for hvad låneinstitutionen må foretage sig i retning af rensning etc., og hvad låneinstitutionen skal gøre såfremt, der sker skader på genstanden, samt hvorvidt og hvordan låneinstitutioner må offentliggøre billeder og tekst vedr. genstanden (Cassar 1995: 129ff; Museum of London 1996).

\section{Konservering}

Det er ikke alle museer, der har en afdeling for konservering, men det siger sig selv, at dette punkt skal udarbejdes i tæt samarbejde med en konservator. Det er således vigtigt at få skabt sammenhæng mellem konservering af de enkelte genstande og den præventive konservering dvs. overvågning, kontrol og styring af det omgivende miljø.

Vedr. konservering af genstandene skal man specificere, hvad man gør, når et konserveringsbehov er erkendt, hvem man henvender sig til med henblik på at få råd og hvem der foretager konservering eller anden behandling. For særlige samlinger, fx zoologiske, vil man måske også ønske at specificere konserveringsmetoder. Endelig bør man også tage stilling til de etiske problemer i forbindelse med rensning/restaurering/konservering (Ashley-Smidt 1994: 11).

Vedr. præventiv konservering betragtes dette område som vitalt, idet et stabilt miljø vil være medvirkende til at reducere behovet for behandling af den ene eller anden art. Retningslinjerne for dette område ses ofte uddybet i særskilte planer, $\mathrm{fx}$ planer for klimastyring (environmental strategies), planer for overvågnings- og kontrolprogrammer (monitoring and control programmes). I disse planer foretages dels en vurdering af risiciområderne: fugtighed, temperatur, lys, inden- og udendørs luftforurening, håndtering og behandling af genstandene og aktiviteterne i museet, dels en fastlæggelse af parametrene for, hvordan museet kan sikre sig mod de ødelæggende faktorer (Cassar 1995; Keene 1996).

\section{Magasiner}

Under dette punkt vil man specificere magasinets opbygning, $\mathrm{fx}$ hvor meget plads der er brug for til de enkelte typer af samlinger, samt en beskrivelse af de enkelte rum og hvordan de skal placeres i forhold til hinanden. Man vil også beskrive hvilke materialer man vil anvende, fx syrefrit papir og bokse, ligesom man vil definere de enkelte samlingers særlige behov og krav til opmagasineringen (Stansfield 1994: 5).

Magasinerne skal være sikre i enhver henseende, dvs. i forhold til klimastyring og i forhold til de sikkerhedsforanstaltninger man træffer mod onde anslag og katastrofer af enhver art, og de skal også være let tilgængelige for personalet, dvs. rimelige at manøvrere rundt i. En detaljeret langtidsplanlægning skal desuden indeholde en vurdering af fremtidige behov til magasinplads, og hvilke typer af magasiner man har behov for. Planlægning bør foregå i tæt samarbejde med konservato- 
rerne (Hilberry \& Weinberg 1994: 155ff; Cassar 1995: 121).

\section{Pakning og transport}

Forkert behandling er en af de største "ødelæggere». Derfor må man stille særlige krav til håndtering af genstande $\mathrm{i}$ forbindelse med indpakning og transport. Hvad disse krav og behov er, skal klarlægges, helst i tæt samråd med konservatorerne, inden retningslinjer og ansvarsområder defineres. De forhold man især skal indskærpe vigtigheden af, er brugen af korrekte metoder til at holde, løfte og bære genstande og brugen af det rigtige værktøj. Desuden skal værktøj og andre hjælpemidler være vedligeholdt og i god stand (Rowlison 1994: 202).

\section{Sikring af samlingerne}

Sikring af samlingerne med tilhørende arkivalier er et spørgsmål om god dokumentation, således at man hele tiden ved præcis, hvor de enkelte ting befinder sig: udlånt, udstillet, på magasin, til konservering etc. (i nogle planer er dette beskrevet under punkt 4). Sikring er også et spørgsmål om risikovurdering af menneskeskabte ødelæggelser og forbrydelser eller naturgivne katastrofer og hvordan man imødegår disse og/eller minimerer skadernes omfang (Stansfield 1994: 53-54). Kodeordene for sikringen af samlingerne er i daglig tale de såkaldte fire A'er: Anticipation, Appraisal, Action, Awareness, dvs. forudseenhed, vurdering, forholdsregler og opmærksomhed.

En fornuftig plan skal udarbejdes på forhånd, og være et resultat af en nøgtern vurdering af risici, ikke et resultat af en dramatisk hændelse. Den skal indeholde klare retningslinjer vedr. pligter, komman- doveje og sikringsudstyr og den inddrager samtlige ansatte i den daglige overvågning. Den vil begrænse effekten af selv de værst tænkelige situationer, uanset om disse forekommer som oversvømmelser, brand eller økonomiske nedskæringer. Sidstnævnte punkt er i øvrigt i stadig stigende grad sat på museernes risikoliste og således et godt udtryk for, hvad mange museer i dag vurderer som en af de største fare for museerne (Sansom 1995b).

\section{Forsikring}

Forsikring af museets bygninger og samlinger, evt. enkelte genstande, skal ske i henhold til ovenstående vurdering af risici. I UK lader museerne sig dels forsikre i private forsikringsselskaber under tilsvarende forhold som her, dels ved især offentlige myndigheder, som påtager sig at holde museet skadeløs eller genoprette eller restaurere ødelagte eller skadede genstande og/eller bygninger. Forsikringsformen kaldes «indemnity», og er sædvanligvis gratis. Det er opbygget efter særlige retningslinjer, $\mathrm{fx}$ påtager staten sig at genopbygge nationale museer, mens de lokale myndigheder påtager sig ansvaret for lokale museer. Punktet skal i øvrigt indeholde retningslinjer for tilføjelse af nyerhvervelser og lån (Office of Arts and Libraries 1995: 288-296).

\section{Udstilling}

Nogle forvaltningsplaner har fyldige planer under dette punkt, andre udarbejder særskilte planer for udstillingerne og nøjes med henvisninger på denne plads. Punktet eller planen vil typisk indeholder retningslinjer for restriktioner $\mathrm{i}$ forbindelse med brugen af genstande og samlinger: maksimumperioden for udstillingen(erne), an- 
48 befalinger for lys, temperatur og fugtighed, opsætning, fastgørelsesmetoder, test af udstillingsmaterialer etc, samt anbefalinger mht. sikringen af genstandene (Payton 1995).

\section{AFRUNDING}

Det var en gennemgang af det angelsaksiske system, og spørgsmålet er naturligvis så, om vi har brug for en tilsvarende stram formalisering af forvaltningen. For at besvare det spørgsmål må man se på udviklingen inden for den danske museumsverdenen.

Tendensen i Danmark såvel som i den angelsaksiske verden er, at den offentlige sektor fra slutningen of 1980'erne til stadighed er blevet konfronteret med skærpede krav om iagttagelse af visse standarder, samtidig med at vi har set en stagnation $i$ de offentlige tilskud. Dette forhold har øget opmærksomheden omkring forvaltningen af museernes samlinger og de tildelte resurser. Selv om vores museer er veletablerede institutioner inden for den danske kulturverden og ikke står over for lige så barske situationer, som dem vi ind imellem ser i England, fungerer de i sammenhæng, økonomisk, politisk og historisk, med det omliggende samfund.

Samtidig har de sidste 10-års udvikling inden for museumsverdenen medført en markant ændring af museernes rolle formidlingsmæssigt, driftsmæssigt og økonomisk. Museernes aktiviteter er ekspanderet, antallet af arbejdsopgaver og dermed også ansatte er øget. Førhen var der måske en eller to ansatte knyttet til et museum. De havde samtlige arbejdsopgaver og områder i hovedet. Det var ikke nødvendigt med formaliserede retningslinjer.
Man kendte opgaverne, vidste hvordan de skulle løses, man kunne kort sagt bedre overskue helheden.

I dag hvor der er mange ansatte inden for flere personalekatagorier og hvor man er nødt til at uddelegere såvel arbejdsopgaver som ansvarsområder, kræves en anderledes systematisk tilgang og en sammenhængende koordination af den fælles forvaltning.

Spørgsmålet er, om ikke mange museer allerede har defineret en del af punkterne i en forvaltningsplan. Man kunne godt forestille sig, at der ligger mange notater rundt omkring på museerne, der er udarbejdet på baggrund af spørgsmål fra offentlige myndigheder etc., og at grunden til en forvaltningsplan således er lagt. Den proces der mangler er at gå i dybden, få fremprovokeret diskussioner, få taget stilling og få arbejdet de enkelte papirer igennem til et samlende hele - og det er jo langt fra den mindste del af opgaven.

\section{LITTERATUR}

Ashley-Smith, J. The ethics of conservation i Care of Collections (red. S Kneel) Routledge 1994, p 11-20.

Babbridge, A. Disposals from museum collections: a note on legal considerations in England and Wales i Collections Management (red. A Fahy) Routledge 1995, p 161-167.

Cassar, M. Environmental Management, Routledge 1995.

Edson, G \& Dean, D. The Handbook for Museums, Routledge 1994.

Fahy, A. Introduction i Collections Management (red. A Fahy) Routledge 1995, p 1-8. 
Hillberry, J D og Weinberg, S K. Museum collections storage i Care of Collections (red. S Kneel) Routledge 1994, p 155-175.

Keene, S. Managing conservation in museums, Butterworth-Heinemann 1996.

Lord, B., Lord, G.D., and Nicks, J. The cost of collecting, Office of Arts and Libraries, London HMSO 1989.

Malero, M. Collection managment policies i Collections Management (red. A Fahy) Routledge 1995, p 11-28.

Museum of London. General conditions of loan, London 1995.

Museums \& Galleries Commission. Guidelines for a Registration Scheme for museums in the United Kingdom i Collections Managegement (red. A Fahy) Routledge 1995, p 35-65.

Office of Arts and Libraries. Indemnity arrangements for local museums, galleries and other non-governmental bodies i Collections Management (red. A Fahy) Routledge 1995, p 288-296.

Payton, R. Noter fra forelæsning i Conservation Management, vedr. udstillingsplanlægning 14. november 1995 .

Robertson, I. Infamous de-accessions i Collections Management (red. A Fahy) Routledge 1995, p 168-171.

Rowlison, E B. Rules for handling works of art i Care of Collection (red. S Kneel) Routledge 1994, p 202-211.

Sansom, E (Sansom 1995a). Noter fra forelæsning i Collections Management vedr. Acquisitions and Disposals, 10. oktober 1995.

Sansom, E (Sansom 1995b). Noter fra forelæsning i Collections Management vedr. disaster planning, 12. december 1995.

Stansfield, G. Collection Management, MA Museum Studies University College London, 1994.
SUMMARY

Collections Management

The author has a masters degree in Museum Studies from University College London. She introduces the subject of collections management and the concept of a collections management policy with regard to standards in America and Britain.

The need to establish policies and procedures in museums is part of the movement towards a more professional approach to museum work. As far as collections management is concerned, the starting point has often been to produce a statement of acquisition policy to show that the museum is acting legally and that it is collecting in a responsible manner. This has led to initiatives from professional associations (ICOM, American Association af Museums, Museums Association etc.) to produce codes of conduct and codes of practise for curators, registrars, conservators, and other museum professionals. The advantages of such a policy are:

- it provides a guide for museum staff in making decisions about collections management;

- it ensures consistency, improves efficiency and avoids conflicts;

- it helps improve public confidence in a museum by showing that it is managed within the law and according to defined professional standards.

A collections management policy covers a broad range of topics:

1 the purpose of the museum and its collection goals

2 the method for acquiring objects

3 the method for disposing of objects

4 documentation

5 access to collections and data

6 incoming and outgoing loan policies

7 conservation

8 storage

9 handling procedures

10 security 
MAIKEN HANSEN

$50 \quad 11$ insurance

12 exhibition.

Each of the topics mentioned raises a host of issues that must be considered, and the very exercise of reviewing and coming to terms with these issues provides a worthwhile educational opportunity for museum officers and staff. It requires much communication among staff members and frank discussion between staff and board members, and areas of uncertainty or disagreement must be resolved and adjustments made. However, the objective of the policy is not to attempt to solve all possible problems, but to define areas of responsibility and to set forth guidelines for those charged with making certain decisions. The policy, therefore, must be detailed enough to provide useful instruction yet at the same time avoid procedural minutia. A policy is normally revised every $3-5$ years.

Maiken Hansen er cand.phil i middelalderarkaologi fra Institut for Middelalderarkoologi, Aarbus Universitet og MA i Museum Studies 1996 fra Department of Archaeology, Conservation and Museum Studies på University College London. Har i flere perioder arbejdet $i$ England.

Adr.: Svejbakvej 4, Sonderskov, DK-8600 Silkeborg. 